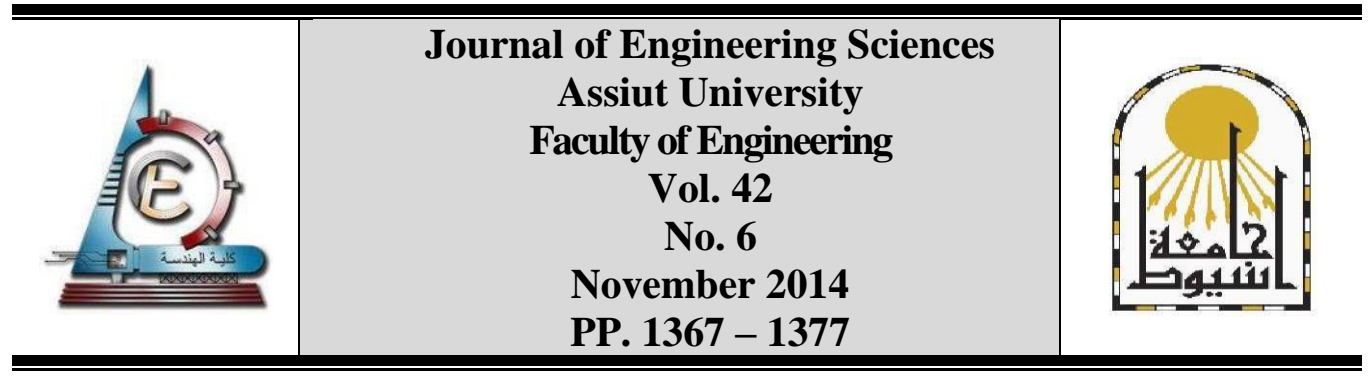

\title{
ELEVATED TEMPERATURE RESISTANCE CONCRETE USING NON-TRADITIONAL MATERIALS
}

\author{
Mohamed M. M. Rashwan, Hesham M. A. Diab and Ahmed Fouad Abdullah Gad \\ Staff in Civil Eng. Depart, Faculty of Eng., Assiut University, Assiut, Egypt
}

(Received 17 November 2014; Revised 28 December 2014; Accepted 3 March 2014)

\begin{abstract}
The properties of materials used in preparing concrete play an important role on the performance of concrete during its lifetime. Concrete generally provides adequate fire resistance for most applications. However, the strength and durability properties of concrete are significantly affected when subjected to elevated temperature. Terrorist attack, accidental fire breakout and different type of explosions produce a rapid change of temperature for a short period. This study was focused on improving the elevated temperature resistance of normal concrete by using Ground Granulated Blast Furnace Slag (GGBFS) as cement replacement and fine aggregate replacement and Brick Break (BB) as coarse aggregate replacement. Different replacement percentages of GGBFS and BB were used in this study $(10 \%, 20 \%$ and 30\%). Percentage of GGBFS replacement was calculated based on the dry weight of cement material, while the percentage of $\mathrm{BB}$ was calculated based on the weight of coarse aggregate. Nine mixes in additional to the reference concrete mix (25 MPa) considered in this study were exposed to high temperatures of 300,600 and $800^{\circ} \mathrm{C}$. Moreover, cooling system effect of heated concrete cubes have been investigated through two cooling procedure [Air cooling and Water cooling (quenching)].

Physical and mechanical properties of the developed mixes including residual compressive strength, mass losses, adsorption, and water absorption have been determined. Test data indicated that high temperature caused significant deterioration in the properties of concrete; the addition of GGBFS and BB could all effectively improve the residual compressive strength of concrete. For all series there is decrease in compressive strength with increase in temperature this decrease reached to $50 \%$ for control mix at $800^{\circ} \mathrm{C}$ in case of slow cooling in air, however the residual compressive strength was 65 and $60 \%$ for mixes containing GGBFS and BB respectively.
\end{abstract}

Keywords: Concrete; Elevated temperature; Cooling; Replacement materials; Ground granulated blast furnace slag; Brick Break; Compressive Strength.

\section{Introduction}

\subsection{Fire performance of normal and high strength concrete}

High temperature exposure leads to a reduction of residual strength of both normal and

* Corresponding author.

Email address: elamer_4all@yahoo.com 
Ahmed Fouad Abdullah Gad et al., Elevated temperature resistance concrete using.............

high strength concretes. There is a minor change in the residual compressive strength up to about $200{ }^{\circ} \mathrm{C}$ and a rapid drop after $350{ }^{\circ} \mathrm{C}$. About $40 \%$ is left after $600{ }^{\circ} \mathrm{C}$ [4]. F.Herna'ndez [8] studied the behavior of a high-strength concrete (HSC) with silica fume (SF) modified with different amounts of solid particles recycled from crumbed used truck tires. Decrease of compressive strength and stiffness, with regard to HSC, when the percentage of rubber in its composition increases. Concretes with pozzolanic materials show better strength results than the pure OPC concretes [5].

Ali Behnoo [2] determined the compressive and splitting tensile strength of high-strength concrete with and without polypropylene fibers (PP) after heating to $600^{\circ} \mathrm{C}$. As ever strength loss was observed for all of the concretes after exposure to $600{ }^{\circ} \mathrm{C}$, particularly the concretes containing silica fume despite their good mechanical properties at room temperature. Ivanka Netinger [11] investigated the benefits of using materials that were formed at high temperatures as an aggregate for concrete that was exposed to high temperature.

\subsection{Fire performance of GGBFS concrete}

GGBFS is an industrial by-product from the iron and steel industry. Because of the technological, economic, and environmental benefits, GGBFS has been gradually replacing cement in concrete in recently years. Isa. Yuksel [10] studied how the usage of bottom ash (BA), granulated blast furnace slag (GBFS), and combination of both of these materials as fine aggregate in concrete affects the concrete durability. As a general result, GBFS and BA affect durability properties of concrete positively when it is used as fine aggregate. Eshmaiel Ganjian [7] conducted experimental investigations on the performance of cement paste and concrete mixes incorporating $7 \%$ and $10 \%$ of silica fume (SF) as a cement replacement in three exposure conditions. The results showed that the SF mix exhibits the highest strength development, while the blended ternary GGBS-SF mix exhibits the lowest strength development [13]. Isa Yuksel [9] studied the influence of high temperature on the properties of concrete containing non-ground granulated blast-furnace slag (GBFS) and coal bottom ash (BA) as fine aggregate. Test results showed that loss in weight due to high temperature effect was independent from the replacement ratio of GBFS.

The effect of the temperature on mass loss of the GGBFS concrete was less than $8 \%$ below $700{ }^{\circ} \mathrm{C}$, which was similar to the ordinary Portland cement (OPC) concrete. The effect of temperatures above $400{ }^{\circ} \mathrm{C}$ on the compressive strength of concrete was more pronounced for concrete containing GGBFS [1]. Ali Reza Bagheri [3] studied the effect of incorporation of silica fume in enhancing strength development rate and durability characteristics of binary concretes containing a low reactivity slag has been investigated. The results showed that combined use of silica fume and slag results in reduced water demand compared to mixes containing silica fume. Ivanka Netinger [12] conducted experimental investigations on the possibility of utilization of the by-products from the steel production industry as aggregates in concrete in order to improve its post-fire properties. The results obtained have shown that slag in lower temperature range (up to $400{ }^{\circ} \mathrm{C}$ ) could improve performance of the tested types of concrete.

\section{Research objectives}

From the previous discussions we found that, the effect of high temperature on concrete containing Ground Granulated Blast-furnace Slag (GGBFS) and silica fume (SF) has not been investigated in details. The preceding review reveals that most of the studies used only 
JES, Assiut University, Faculty of Engineering, Vol. 42, No. 6, November 2014, pp. 1367 - 1377

one or maximum two pozzolans at different dosage levels in concrete to evaluate its fire performance. This research investigates the effect of Ground Granulated Blast Furnace Slag (GGBFS) and Brick Break (BB) on the performance of concrete at elevated temperatures.

\section{Experimental work}

\subsection{Material}

Local Ordinary Portland Cement from Assiut Cement Factory was used and its properties are given in Table (1) and (2) it met the requirements of E.S.S [6]. Local sand and gravel were used. Local Brick Break (BB) was used as coarse aggregate (Red Brick Break) and its properties are given in Table (3) and (4) it met the requirements of E.S.S [6]. Ground granulated blast furnace slag (GGBFS), solid waste discharged in large quantities by the iron and steel industry, was obtained from EL-Garhi factory for iron and steel in Egypt. Its properties are given in Table (1) \& (2). Silica fume; it is produced by EFACO.

Table 1.

Physical properties of cementitious materials.

\begin{tabular}{|c|c|c|c|}
\hline \multicolumn{2}{|c|}{ Physical test } & Cement & GGPFS \\
\hline \multicolumn{2}{|c|}{ Initial setting time (minutes) } & 70 & -- \\
\hline \multicolumn{2}{|c|}{ Final setting time (hours) } & 8.25 & -- \\
\hline \multicolumn{2}{|c|}{ Specific surface area $\left(\mathrm{cm}^{2} / \mathrm{gm}\right)$} & 3500 & 3200 \\
\hline \multicolumn{2}{|c|}{ Specific gravity } & 3.15 & 3 \\
\hline \multirow{2}{*}{ Compressive strength (MPa.) } & 7- day & 21 & -- \\
\hline & 28- day & 29 & -- \\
\hline
\end{tabular}

Table 2.

Chemical properties of cementitious materials.

\begin{tabular}{|c|c|c|c|c|c|c|c|}
\hline $\begin{array}{c}\text { Oxide compositions } \\
(\%)\end{array}$ & $\mathrm{SiO}_{2}$ & $\mathrm{AL}_{2} \mathrm{O}_{3}$ & $\mathrm{Fe}_{2} \mathrm{O}_{3}$ & $\mathrm{CaO}$ & $\mathrm{MgO}$ & $\mathrm{Na}_{2} \mathrm{O}$ & $\mathrm{K}_{2} \mathrm{O}$ \\
\hline Cement & 19.2 & 6.45 & 3.45 & 63.17 & 1.31 & -- & -- \\
\hline GGBFS & 37.2 & 16.32 & 0.6 & 36.3 & 11.2 & 0.31 & 0.42 \\
\hline
\end{tabular}

\section{Table 3.}

Chemical properties of aggregate.

\begin{tabular}{|c|c|c|c|}
\hline Property & Sand & Gravel & Brick break \\
\hline \% of chloride ions & 0.04 & 0.008 & 0.018 \\
\hline \%of Sulphates ions & 0.129 & 0.012 & 0.04 \\
\hline PH & 8.5 & 8 & 3.5 \\
\hline
\end{tabular}

\section{Table 4.}

Physical properties of aggregate.

\begin{tabular}{|c|c|c|c|c|}
\hline \multicolumn{2}{|c|}{ Property } & Sand & Gravel & Brick break \\
\hline \multicolumn{2}{|c|}{ Specific gravity } & 2.5 & 2.5 & 1.56 \\
\hline \multirow{2}{*}{ Unite weight $\left(\mathrm{t} / \mathrm{m}^{3}\right)$} & Loose & 1.44 & 1.56 & 0.98 \\
\hline & Compact & 1.6 & 1.67 & 1.03 \\
\hline \multicolumn{2}{|c|}{ Crushing factor $(\%)$} & --- & 19.7 & 49.43 \\
\hline \multicolumn{2}{|c|}{ Maximum nominal size $(\mathrm{mm})$} & --- & 40 & 40 \\
\hline \multicolumn{2}{|c|}{ Fineness modulus } & 2.45 & 7.11 & 7.7 \\
\hline \multicolumn{2}{|c|}{ Specific surface area $\left(\mathrm{cm}^{2} / \mathrm{gm}\right)$} & 56.24 & 2.06 & 2.03 \\
\hline
\end{tabular}


Ahmed Fouad Abdullah Gad et al., Elevated temperature resistance concrete using.............

\subsection{Design of concrete mix}

In order to investigate the effect of the different parameters four groups were prepared for this. The mixtures, description and quantities of the various materials for each designed concrete mixture are given in Table (5), (6). One control mixture (R) was designed per E.S.S [6] to have 28-day compressive strength of $25 \mathrm{MPa}$. The concrete mixtures, viz. $\mathrm{C}_{1}$ to $\mathrm{C}_{3}$, were made with replacement levels of $10 \%, 20 \%$ and $30 \%$ of GGBFS by weight of cement in addition to constant ratio of silica fume equal to $10 \%$ by weight of cement and conducted this weight from weight of cement. The concrete mixtures, viz. $S_{1}$ to $S_{3}$, were made with replacement levels of 10\%, 20\% and 30\% of GGBFS by weight of cement and conducted this weight from weight of sand in addition to constant ratio of silica fume equal to $10 \%$ by weight of cement and conducted this weight from weight of cement. The concrete mixtures, viz. $\mathrm{G}_{1}$ to $\mathrm{G}_{3}$, were made with replacement levels of $10 \%, 20 \%$ and $30 \%$ of brick break by weight of combined coarse aggregate and conducted this weight from weight of combined coarse aggregate.

Table 5.

Percentage of replacement materials.

\begin{tabular}{|c|c|c|c|c|c|c|c|}
\hline \multirow[t]{2}{*}{ Mixture } & \multirow[t]{2}{*}{ Cement } & \multirow{2}{*}{$\begin{array}{c}\text { GGBFS } \\
\text { by weight } \\
\text { of cement }\end{array}$} & \multirow{2}{*}{$\begin{array}{c}\text { Silica } \\
\text { by weight } \\
\text { of cement }\end{array}$} & \multirow{2}{*}{$\begin{array}{c}\text { BB by } \\
\text { weight of } \\
\text { combined } \\
\text { coarse } \\
\text { aggregate }\end{array}$} & \multicolumn{2}{|c|}{$\begin{array}{l}\text { Percentage of } \\
\text { aggregate relative to } \\
\text { control mix }\end{array}$} & \multirow[t]{2}{*}{$\mathrm{S} / \mathrm{G}$} \\
\hline & & & & & sand & gravel & \\
\hline $\mathrm{R}$ & 100 & --- & --- & --- & 100 & 100 & 0.58 \\
\hline $\mathrm{C}_{1}$ & 80 & 10 & 10 & --- & 99.25 & 99.25 & 0.58 \\
\hline $\mathrm{C}_{2}$ & 70 & 20 & 10 & --- & 99.18 & 99.18 & 0.58 \\
\hline $\mathrm{C}_{3}$ & 60 & 30 & 10 & --- & 99.11 & 99.11 & 0.58 \\
\hline$S_{1}$ & 90 & 10 & 10 & --- & 94.71 & 99.46 & 0.55 \\
\hline $\mathrm{S}_{2}$ & 90 & 20 & 10 & --- & 89.42 & 99.97 & 0.52 \\
\hline $\mathrm{S}_{3}$ & 90 & 30 & 10 & --- & 84.13 & 100.48 & 0.49 \\
\hline $\mathrm{G}_{1}$ & 100 & --- & --- & 10 & 97.69 & 87.93 & 0.58 \\
\hline $\mathrm{G}_{2}$ & 100 & --- & --- & 20 & 95.04 & 76.05 & 0.58 \\
\hline $\mathrm{G}_{3}$ & 100 & --- & --- & 30 & 92.61 & 64.83 & 0.58 \\
\hline
\end{tabular}

Table 6.

Amounts of constituent materials by weight required for one cubic meter of concrete for the used different mixes.

\begin{tabular}{|c|c|c|c|c|c|c|c|c|c|}
\hline Mixture & $\begin{array}{c}\text { Cement } \\
\left(\mathrm{kg} / \mathrm{m}^{3}\right)\end{array}$ & W/C & $\begin{array}{c}\text { GGBFS } \\
\left(\mathrm{kg} / \mathrm{m}^{3}\right)\end{array}$ & $\begin{array}{c}\text { Silica } \\
\left(\mathrm{kg} / \mathrm{m}^{3}\right)\end{array}$ & $\begin{array}{c}\text { Sand } \\
\left(\mathrm{kg} / \mathrm{m}^{3}\right)\end{array}$ & $\begin{array}{c}\text { Gravel } \\
\left(\mathrm{kg} / \mathrm{m}^{3}\right)\end{array}$ & $\begin{array}{c}\text { Brick } \\
\text { break } \\
\left(\mathrm{kg} / \mathrm{m}^{3}\right)\end{array}$ & $\begin{array}{c}\text { Water } \\
\left(\mathrm{L} / \mathrm{m}^{3}\right)\end{array}$ & $\begin{array}{c}\text { Slump } \\
(\mathrm{Cm})\end{array}$ \\
\hline $\mathrm{R}$ & 350 & 0.48 & -- & -- & 661.6 & 1140.6 & -- & 168 & 11 \\
\hline $\mathrm{C}_{1}$ & 280 & 0.48 & 35 & 35 & 656.7 & 1132.2 & -- & 168 & 9 \\
\hline $\mathrm{C}_{2}$ & 245 & 0.48 & 70 & 35 & 656.2 & 1131.3 & -- & 168 & 8.5 \\
\hline $\mathrm{C}_{3}$ & 210 & 0.48 & 105 & 35 & 655.6 & 1130.4 & -- & 168 & 8 \\
\hline $\mathrm{S}_{1}$ & 315 & 0.48 & 35 & 35 & 626.6 & 1134.5 & -- & 168 & 10 \\
\hline $\mathrm{S}_{2}$ & 315 & 0.48 & 70 & 35 & 591.6 & 1140.3 & -- & 168 & 9 \\
\hline $\mathrm{S}_{3}$ & 315 & 0.48 & 105 & 35 & 556.6 & 1146.1 & -- & 168 & 8.5 \\
\hline $\mathrm{G}_{1}$ & 350 & 0.48 & -- & -- & 646.3 & 1002.9 & 111.4 & 168 & 9 \\
\hline $\mathrm{G}_{2}$ & 350 & 0.48 & -- & -- & 628.8 & 867.4 & 216.8 & 168 & 8 \\
\hline $\mathrm{G}_{3}$ & 350 & 0.48 & -- & -- & 612.7 & 739.4 & 316.9 & 168 & 7 \\
\hline
\end{tabular}




\subsection{Preparation, casting and curing of test specimens}

Cubes moulds of size $150 * 150 * 150 \mathrm{~mm}$ were used to prepare the concrete specimens for the determination of compressive strength, mass loose, absorption and adsorption. All specimens were prepared in accordance with E.S.S. [6]. After carrying out the tests for fresh concrete, final casting of the mixes was done immediately. After casting test specimens were remained in the steel mould for the first $24 \mathrm{~h}$ at ambient conditions. They were then remoulded with care so that no edges were broken and placed in the curing tank at the ambient temperature.

\subsection{Heating and cooling regimes}

\subsubsection{Electric furnace temperature build-up}

After 28 days curing, the specimens were weighted and then placed in a closed electric furnace up to 300,600 and $800^{\circ} \mathrm{C}$. The temperature was maintained at the respective temperature for (1hr) to achieve a thermally steady state.

\subsubsection{Specimen cooling}

After exposing the cubes to design temperature they were removed from the furnace. Then the half of each group allowed to cool naturally to room temperature for $24 \mathrm{hr}$ (Air cooling) and the other half placed in tank of water which was allowed for 24hr (Sudden cooling). All of specimens after removed from the furnace were weighted before and after cooling.

\subsection{Testing procedures}

After the concrete specimens were cooled to the room temperature, the compressive strength, mass loss, absorption and adsorption were determined. The tests were performed according to E.S.S [6]. It was found that unstressed residual strength test gives the lowest strength and is therefore more suitable for getting the limiting values and hence selected for this research [14].Three specimens from each group for all different condition were used to determine of the compressive strength at 28 day for all groups and at 90 day for group (C) only. The axial static compression load was applied using a compression machine with a capacity of 150 ton.

\section{Results and Discussion}

\subsection{Slump}

The slump of concrete with different replacement material content was showed in Table (7). For C \& S series with increase in percentage replacement of OPC with GGBFS, the workability decrease. This is attributed to, the roughness of GGBFS and high percentage of carbon content of it. For $\mathrm{G}$ series with increase in percentage replacement of gravel with Brick Break (BB), the workability decrease i.e the water consumed by Brick Break during mixing is very high as compared with gravel. This is as a result of, the roughness, the irregular shape after crushing and carbon content of BB.

Table 7.

Slump values for different series.

\begin{tabular}{|c|c|c|c|c|c|c|c|c|c|c|}
\hline \multirow{2}{*}{ Mix } & \multirow{2}{*}{$\mathrm{R}$} & \multicolumn{3}{|c|}{ C series } & \multicolumn{3}{c|}{ S series } & \multicolumn{3}{c|}{ G series } \\
\cline { 3 - 12 } & & $\mathrm{C}_{1}$ & $\mathrm{C}_{2}$ & $\mathrm{C}_{3}$ & $\mathrm{~S}_{1}$ & $\mathrm{~S}_{2}$ & $\mathrm{~S}_{3}$ & $\mathrm{G}_{1}$ & $\mathrm{G}_{2}$ & $\mathrm{G}_{3}$ \\
\hline Slump $(\mathrm{Cm})$ & 11 & 9 & 8.5 & 8 & 10 & 9 & 8.5 & 9 & 8 & 7 \\
\hline
\end{tabular}


Ahmed Fouad Abdullah Gad et al., Elevated temperature resistance concrete using.............

\subsection{Loss of weight after exposure to elevated temperatures}

The mass of concrete specimens was measured and the losses in mass were calculated and compared. The effect of elevated temperature on the mass loss of concrete is shown in Fig.(1). It is observed that, for $\mathbf{C} \boldsymbol{\&} \mathbf{S}$ series there is increase in percentage loss in weight with increase in temperature. Similar results were reported by [4, 9, and 15]. For any temperature, there is increase in percentage loss in weight with increase in replacement ratio of GGBFS. There may be too many causes of loss in weight after high temperature exposure. However spalling or expulsions of chunks of material from the surface layers are principal causes of loss in weight. For $\mathbf{G}$ series there is increase in percentage loss in weight with increase in temperature. It showed that behaviour of concrete was not affected significantly with the substitution of Brick Break as a coarse aggregate.

\subsection{Water absorption test}

The effect of elevated temperature on absorption of concrete is shown in Fig.(2). For all mixes, there is increase in percentage of absorption with increase in temperature this may be due to the evaporation of physically absorbed water starts at $80^{\circ} \mathrm{C}$, which induces thermal cracks. It is observed from Fig.(2) that, at $800{ }^{\circ} \mathrm{C} \mathrm{C}_{2} \& \mathrm{~S}_{2}$ mix were given the lowest value of percentage of absorption. For G series it showed that, behaviour of concrete was not affected significantly with the substitution of Brick Break as a coarse aggregate.

\subsection{Adsorption}

The effect of elevated temperature on adsorption of concrete is shown in Fig.(3). For all mixes, there is decrease in percentage of adsorption with increase in temperature. For $\mathbf{C}$ series at any temperature, there is decrease in percentage of adsorption with increase in replacement ratio of GGBFS. For $\mathbf{S}$ series at any temperature, there is increase in percentage of adsorption with increase in replacement ratio of GGBFS. For $\mathbf{G}$ series it showed that, behaviour of concrete was not affected significantly with the substitution of Brick Break as a coarse aggregate.

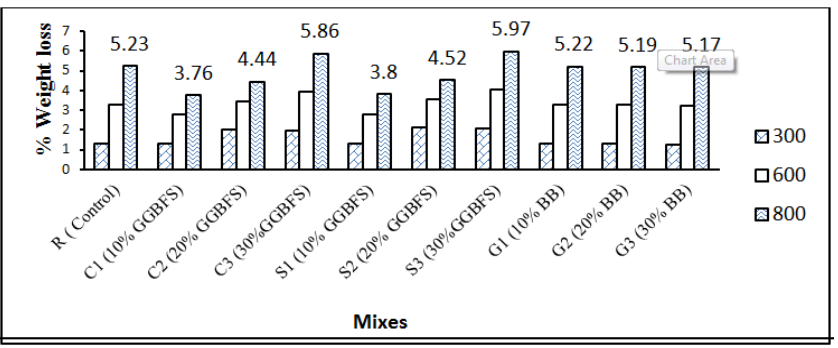

Fig.1. Effect of temperature on loss in weight of concrete exposed to elevated temperature.

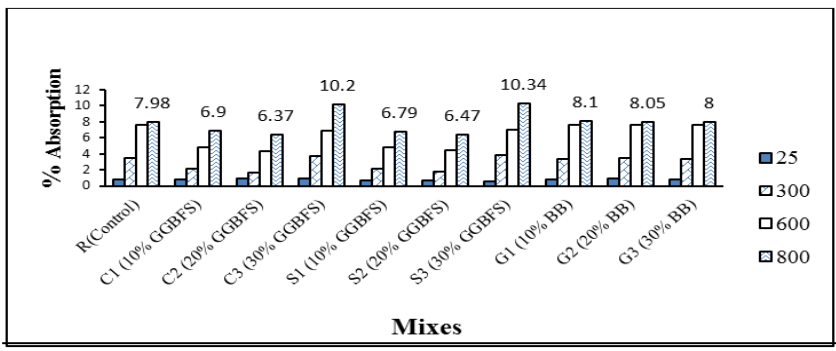

Fig. 2. Effect of temperature on absorption of concrete exposed to elevated temperature. 


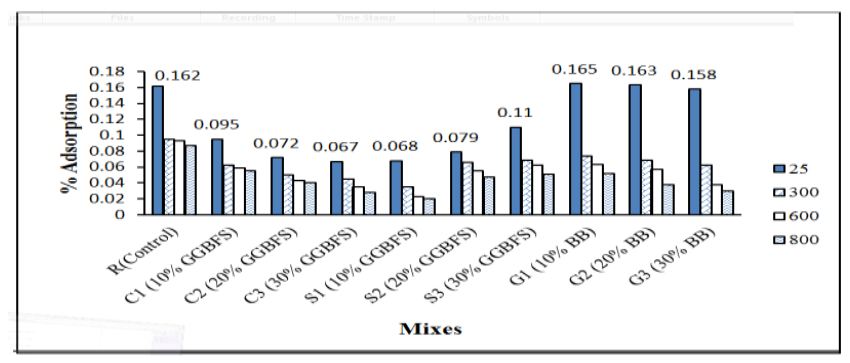

Fig. 3. Effect of temperature on adsorption of concrete exposed to elevated temperature.

\subsection{Compressive strength for different cooling procedure after 28 days}

\subsubsection{Air cooling}

The test results indicate that, for all series there is decrease in compressive strength with increase in temperature this could be attributed to the development of microcracks caused by differences in thermal expansion coefficients between components and by calcium hydroxide decomposition. The strength ratio $\mathrm{F}_{\mathrm{T}} / \mathrm{F}_{25}$ as a function of the specimens' temperature $\mathrm{T}$ is shown in Fig.(7) where $\mathrm{F}_{\mathrm{T}}$ : the compressive strength at any temperature $\mathrm{T}$ and $\mathrm{F}_{25}$ : the compressive strength at room temperature. It is showed that,

For $\mathbf{C}$ series, $\mathrm{C}_{2}$ mix does the best performance at elevated temperatures compared with the other mixes, $\%$ increasing of compressive strength relative to control mix at $800^{\circ} \mathrm{C}$ reached to $19.22 \%$. At room temperature, compressive strength of all mixes decrease compare with control mix this may be due to, specific weight of GGBFS is less than specific weight of cement this lead to increase in volume of voids.

For $\mathbf{S}$ series, $\mathrm{S}_{2}$ mix does the best performance at elevated temperatures compared with the other mixes, \% increasing of compressive strength relative to control mix at $800^{\circ} \mathrm{C}$ reached to $37.09 \%$. At room temperature the compressive strength of $S_{2}$ mix exceed than the compressive strength of control mix by $5.4 \%$ this behaviour may be attributed to the positive effect of slag as a fine aggregate replacement [11]. Specific weight of GGBFS is higher than specific weight of sand which leads to decrease the volume of voids in concrete containing slag so, the compressive strength of $S_{2}$ mix increase at room temperature.

For $\mathbf{G}$ series, at elevated temperature, the performance of concrete is increasing up to $30 \%$ replacement ratio of Brick Break $(\mathrm{BB})$. This means that replacement of gravel with $\mathrm{BB}$ does positive effects on resistance to high temperature. Comparing the three mixes according to their concrete strength, the strength increase in $G_{3}$ mix as compared to $G_{1} \& G_{2}$ mix, \% increasing of compressive strength relative to control mix at $800^{\circ} \mathrm{C}$ reached to $23.16 \%$.

\subsubsection{Water cooling (quenching)}

Sudden cooling in water caused additional compressive strength losses reached to $10 \%$ approximately compared with slow cooling in air at all test temperatures. Furthermore, during cooling concrete goes through further damage. This damage is minimized if the cooling rate is very low, but the case in our experiments using high cooling rate by water (quenching). Moreover, thermal shock produced by water cooling or quenching may produce a destructive effect in concrete [1]. The strength ratio $F_{T} / F_{25}$ as a function of the specimens' temperature T is shown in Fig. (8), it is observed that, 
Ahmed Fouad Abdullah Gad et al., Elevated temperature resistance concrete using.............

For $\mathbf{C}$ series, the use of the low reactivity slag at $20 \%$ cement replacement level has caused a small reduction in strength loss at elevated temperatures compared with the other mixes, \% increasing of compressive strength relative to control mix at $800^{\circ} \mathrm{C}$ reached to $32.26 \%$.

For $\mathbf{S}$ series, the performance of concrete is decreasing after $20 \%$ replacement ratio of GGBFS at any temperature.Comparing the three mixes according to their concrete strength, the strength increase in $\mathrm{S}_{2}$ mix as compared to $\mathrm{S}_{1} \& \mathrm{~S}_{3}$ mix, \% increasing of compressive strength relative to control mix at $800^{\circ} \mathrm{C}$ reached to $52.1 \%$.

For $\mathbf{G}$ series, at elevated temperature, the performance of concrete is increasing up to $30 \%$ replacement ratio of Brick Break (BB). This means that replacement of gravel with BB does positive effects on resistance to high temperature. Comparing the three mixes according to their concrete strength, the strength increase in $\mathrm{G}_{3}$ mix as compared to $\mathrm{G}_{1} \& \mathrm{G}_{2} \mathrm{mix}$, \% increasing of compressive strength relative to control mix at $800^{\circ} \mathrm{C}$ reached to $35.38 \%$.

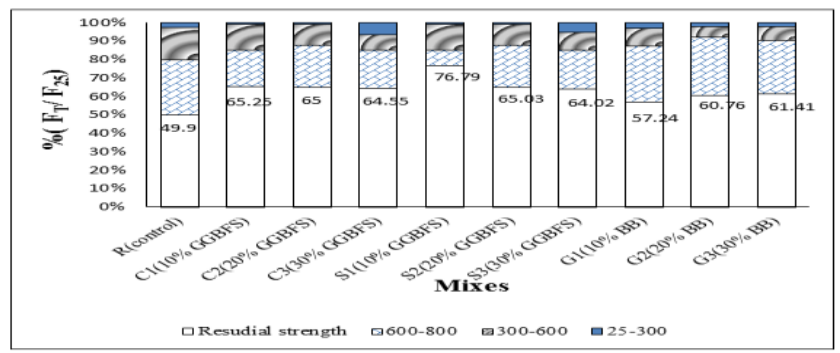

Fig. 7. Effect of temperature on percentage of residual compressive strength relative to reference temperature at the age of 28 day (Air cooling).

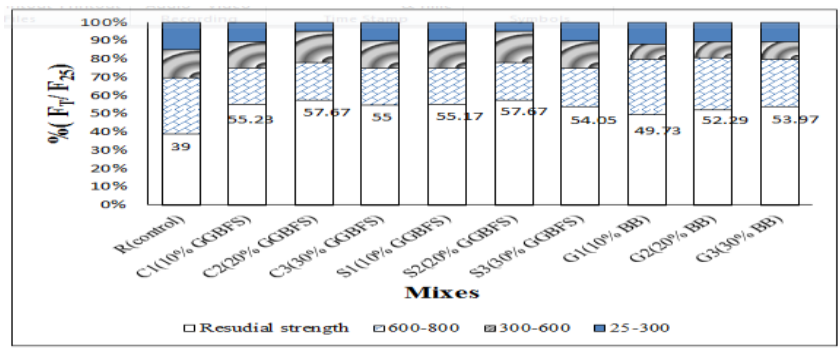

Fig. 8. Effect of temperature on percentage of residual compressive strength relative to reference temperature at the age of 28 day (Water cooling).

\subsection{Compressive strength for different cooling procedure after 90 day}

The strength ratio $F_{T} / F_{25}$ as a function of the specimens' temperature $T$ is shown in Fig.(9) and (10) for air cooling and quenching respectively it is observed that,

For control mix, test results indicate that, after 90 day the performance of control mix still constant approximately compared with the test results after 28 day. \% Relative strength after 28 day at $800^{\circ} \mathrm{c}$ relative to room temperature for different cooling procedure (Air and Water) were 49.9 and $39 \%$ respectively, however after 90 day became 50.1 and 41.15 $\%$.For C series, test results indicate that, after 90 day the performance of $\mathrm{C}_{2}$ mix improved compared with the test results after 28 day. \%Relative strength after 28 day at $800^{\circ} \mathrm{c}$ relative to control mix for different cooling procedure (Air and Water) were 119.22 and $132.26 \%$ respectively, but after 90 day became 134.52 and $150.52 \%$. 


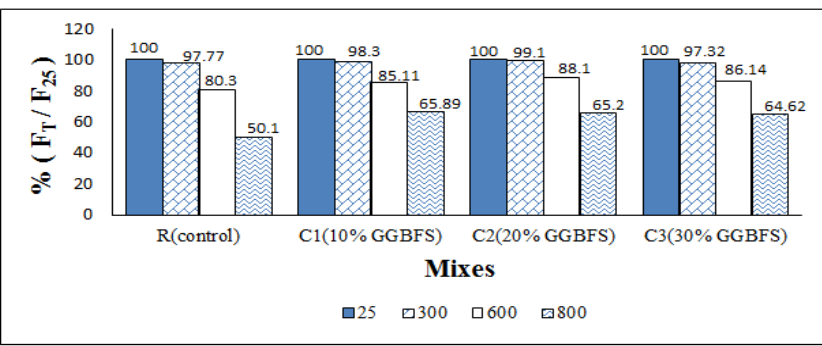

Fig. 9. Effect of temperature on percentage of residual compressive strength relative to reference temperature at the age of 90 day (Air cooling).

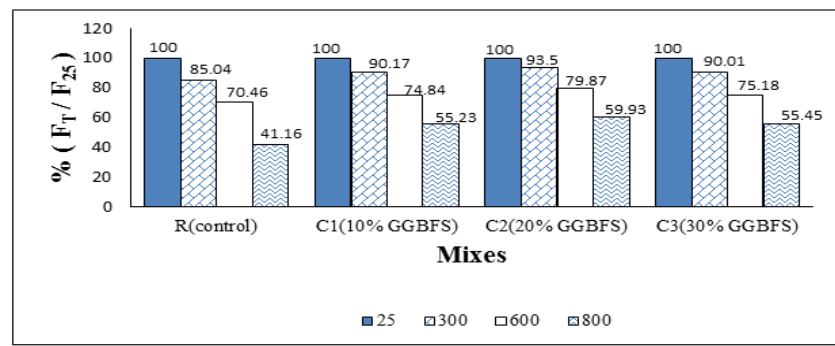

Fig. 10. Effect of temperature on percentage of residual compressive strength relative to reference temperature at the age of 90 day (Water cooling).

\section{Conclusions}

Based on the experimental results, the following conclusions are drawn:

(a) The specimen unit weights decrease with increasing temperature. For control mix the percentage of loss in weight at $300{ }^{\circ} \mathrm{C}, 600{ }^{\circ} \mathrm{C}$ and $800{ }^{\circ} \mathrm{C}$ was $1.31,3.29$ and $5.23 \%$ respectively. For $\mathrm{C} \& \mathrm{~S}$ series at any temperature, there is increase in percentage loss in weight with increase in replacement ratio of GGBFS. At $800{ }^{\circ} \mathrm{C}, \%$ loss in weight for $\mathrm{C}_{3}$ and $\mathrm{S}_{3}$ was 5.86 and $5.97 \%$ respectively.

(b) For all mixes, there is increase in percentage of absorption with increase in temperature. For $\mathrm{C}$ series, at room temperature there is increase in percentage of absorption with increase in replacement ratio of GGBFS. For S series, at room temperature there is decrease in percentage of absorption with increase in replacement ratio of GGBFS.

(c) For all mixes, there is decrease in percentage of adsorption with increase in temperature. For $\mathrm{C}$ series, at any temperature, there is decrease in percentage of adsorption with increase in replacement ratio of GGBFS. For $S$ series, at any temperature, there is increase in percentage of adsorption with increase in replacement ratio of GGBFS. For G series, at elevated temperature, there is decrease in percentage of adsorption with increase in replacement ratio of BB.

(d) The test results indicate that, for all series there is decrease in compressive strength with increase in temperature. $\mathrm{C}_{2}, \mathrm{~S}_{2}$ and $\mathrm{G}_{3}$ mix does the best performance at elevated temperatures compared to the other mixes. Sudden cooling in water caused additional losses in compressive strength reached to (7-11)\% approximately compared to slow cooling in air at all test temperatures.

\section{Research applications}

Further many modern concrete structures are frequently subjected to elevated temperatures due to exposure to an aggressive fire or heat source such as, the concrete structures including 
Ahmed Fouad Abdullah Gad et al., Elevated temperature resistance concrete using.............

nuclear reactor vessels, clinker silos of cement plants, metallurgical and chemical industrial structures, glass making industrial structures and storage tanks for hot crude oils.

\section{REFERENCES}

[1] Ahmed MS, Kayali O., Anderson W., "Chloride penetration in binary and ternary blended cement concretes as measured by two different rapid methods", Cement Concrete Composite, 2008, 30(7):576-82.

[2] Ali Behnood, Masoud Ghandehari, "Comparison of compressive and splitting tensile strength of high-strength concrete with and without polypropylene fibers heated to high temperatures", Fire Safety Journal, 44 (2009) 1015-1022.

[3] Ali Reza Bagheri, Hamed Zanganeh, Mohamad Mehdi Moalemi, "Mechanical and durability properties of ternary concretes containing silica fume and low reactivity blast furnace slag", Cement \& Concrete Composites, Science Direct, 34 (2012) 663-670.

[4] A.N.Noumowe, P.Clastres, G.DebickP, J.L.Costaz, "Transient heating effect on high strength concrete", Nuclear Engineering and Design, 166 (1996), 99-108.

[5] A. Savva, P. Manita, K.K. Sideris, "Influence of elevated temperatures on the mechanical properties of blended cement concretes prepared with limestone and siliceous aggregates", Cement \& Concrete Composites, 27 (2005) 239-248.

[6] Egyptian Code for Design and Construction of R.C. structures, 2010.

[7] Eshmaiel Ganjian, Homayoon Sadeghi Pouya, "The effect of Persian Gulf tidal zone exposure on durability of mixes containing silica fume and blast furnace slag", Construction and Building Materials, Science Direct, 23 (2009) 644-652.

[8] F. Herna'ndez-Olivaresa, G. Barluengab, "Fire performance of recycled rubber-filled highstrength concrete", Cement and Concrete Research, 34 (2004) 109- 117.

[9] Isa Yuksel, Rafat Siddique, Omer Ozkan, "Influence of high temperature on the properties of concretes made with industrial by-products as fine aggregate replacement", Construction and Building Materials, 25 (2011) 967-972.

[10] Isa Yuksel, Turhan Bilir, Omer Ozkan, "Durability of concrete incorporating non-ground blast furnace slag and bottom ash as fine aggregate", Building and Environment ,42 (2007) 2651-2659.

[11] Ivanka Netinger, IvanaKesegic, IvicaGuljas, "The effect of high temperatures on the mechanical properties of concrete made with different types of aggregates", Fire Safety Journal, 46 (2011) 425-430.

[12] Ivanka Netinger, Marija Jel i Rukavina, Ana Mladenovi, "Improvement of post-fire properties of concrete with steel slag aggregate", Procedia Engineering, ScienceDirect, 62 ( 2013 ) $745-753$.

[13] Jawahar Nagar, Shameerpet Mandal, Ranga Reddy Dist, " High performance concrete with GGBS and RABO sand", International Journal of Engineering Science and Technology Vol. 2(10), 2010, 5107-5113.

[14] L.T. Phan, Fire Performance of High Strength Concrete: A Report of the State-of-the-Art, Building and Fire Research Laboratory, National Institute of Standards and Technology, Maryland, 1996.

[15] Qingtao Li , Zhuguo Li, Guanglin Yuan, "Effects of elevated temperatures on properties of concrete containing ground granulated blast furnace slag as cementitious material", Construction and Building Materials, Science Direct, 35 (2012) 687-692. 


\section{خرسانة مقاومة للحرارة و الحريق باستخذام مواد غير تقليدية 6 الماية}

\section{الملخص العربي}

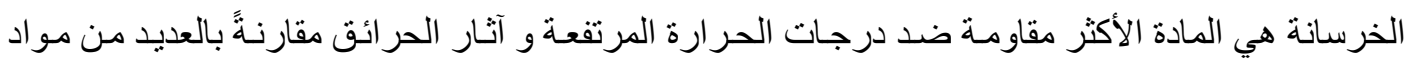

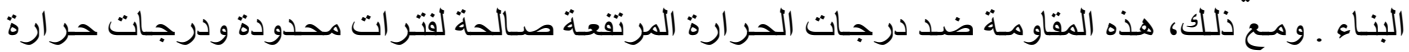

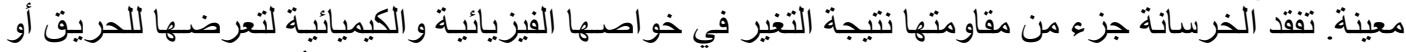

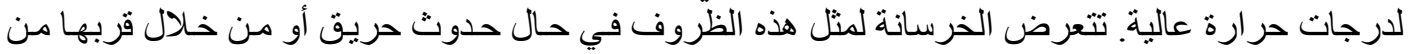

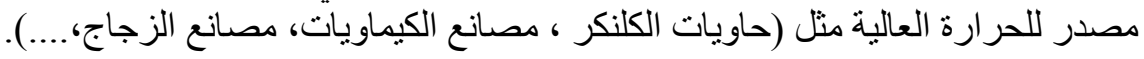

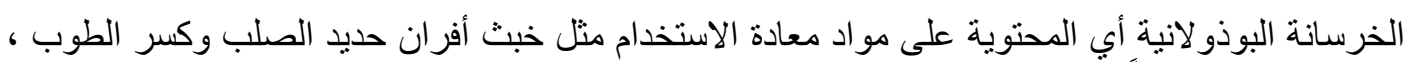

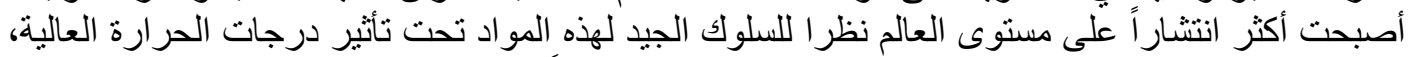

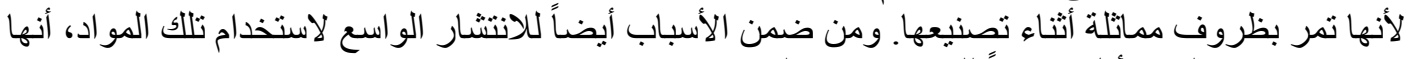

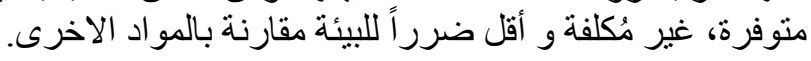

وقد توصل الباحثون إلى نتائج طيبة في هذا المجال من حيث قدرتهم على استخدام تلك الخرسانة لمقاومة

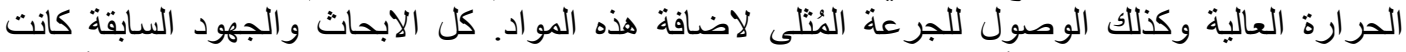

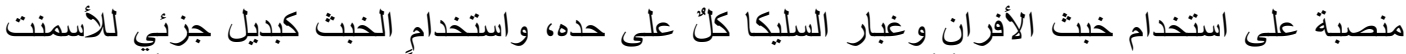

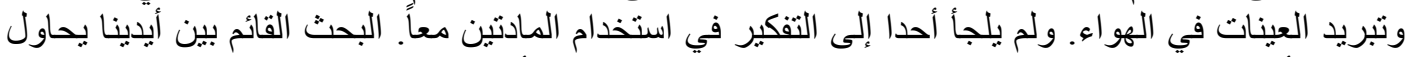

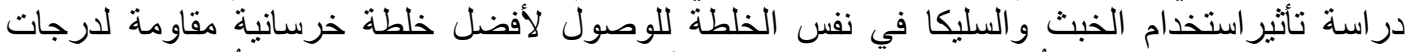

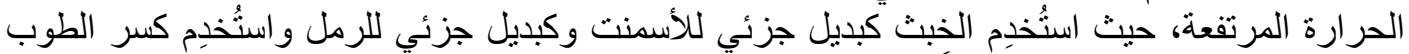

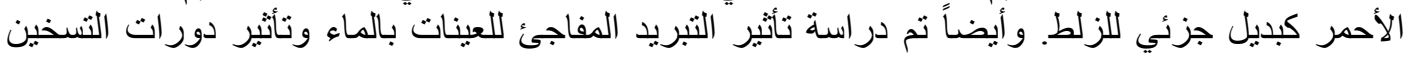
و التبريد بالماء على هذه العينات.

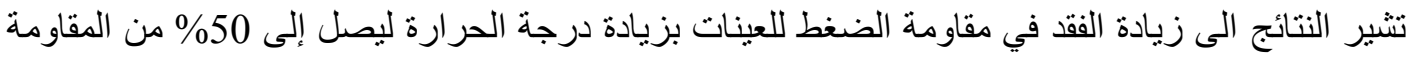

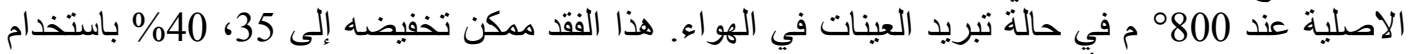

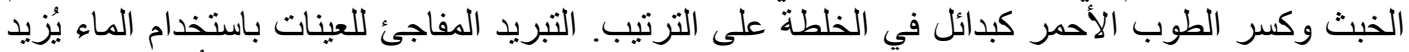

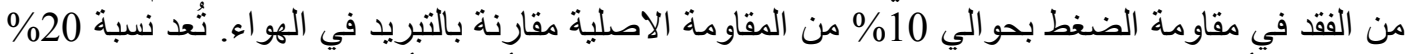

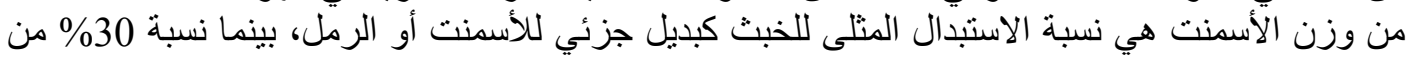

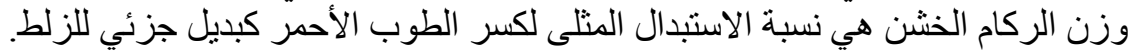

